\title{
The Effects of Information and Communication Technology Based Approach and Laboratory Training Model of Teaching on Achievement and Retention in Chemistry
}

\author{
Alireza Badeleh \\ Islamic Azad University, Sari Branch, Iran \\ G. Sheela \\ University of Mysore, India
}

\begin{abstract}
The purpose of the present study was to investigate the effectiveness of the Information and Communication Technology (ICT) based approach and the Laboratory Training Model of Teaching (LTM) chemistry. It strived to determine whether the ICT or the LTM would be more effective with respect to the male and female students' overall as well as component-based achievement in chemistry and their retention of learning. The sample of the study consisted of 120 seventh standard students from two English-medium elementary schools in Mysore city, India. Four homogenous groups were formed randomly for the study and the effects of independent variables were tested under experimental conditions. The Test of Higher Mental Ability in Science (THMAS) was used to determine the homogeneity of the participants. After one month, the delayed posttest for achievement in chemistry was administered to determine the retention level of the students. The statistical techniques used to analyze the data were the independent sample t-test and two-way analysis of variance (ANOVA). The findings indicated that as far as the overall achievement in chemistry, component-based achievement, and retention of knowledge, comprehension, application, and skills are concerned, the ICTbased method of teaching chemistry was more effective than the LTM of teaching. The effects of gender varied according to comparisons.
\end{abstract}

Keywords: Information and communication technology; Laboratory training model of teaching; Achievement in chemistry; Retention of learning

\section{Introduction}

In the traditional learning environment, it is the teacher who transfers knowledge to the learner through the medium of printed materials, particularly textbooks. There is not much technology usage, and the practice of asking students to collaborate is often lacking. However, the truly Information and Communication Technology (ICT) based learning is a form of education that occurs through the multimedia in class environment; it does not consist of any physical learning materials issued to students or actual face-to-face contact. This type of learning environment has been claimed to promote opportunities for collaborative learning, explorative learning or engaged 
learning. For example, students will be able to go on an information journey around the world to search for and collect information. In addition to gaining access to databases, networking will enable the students to engage in communications and collaborations with other students, teachers, and people everywhere (Ya'acob, Mohd Nor, \& Azman, 2005).

ICT-based learning brought about an increased tendency toward collaborative learning among students and teachers, not only in a particular classroom. This type of interaction is in contrast to the traditional learning environment. The rapid growth of ICT has led to 'revolutions in learning' as each new technological innovation in education has entailed the reinvention of the wheel and the application of new methods/instruments in teaching-learning practices. ICT is a means of storing, processing, and presenting information electronically through a number of media. Computers and microelectronic devices are built into a wide variety of everyday objects. However, the types of technologies incorporated in the educational context tend to focus around the delivery of content and information to support formal learning processes. ICTs, which include radio and television, as well as newer digital technologies such as computers and the Internet-, have been touted as potentially powerful enabling tools for educational change and reform (Tinio, 2003).

ICT approach is a modern method that is used in schools and it can and will empower teachers and learners, transforming teaching and learning processes from being highly teacher-dominated to student-centered. This transformation will result in increased learning gains for students, creating and allowing for opportunities for learners to develop their creativity, problem-solving abilities, informational reasoning skills, communication skills, and other higher-order thinking skills. During the last several decades the availability of increasingly sophisticated software has grown steadily. Throughout the world personal computers and the internet have become a part of childhood and adolescence. The rapid developments in hardware technology have led to enhanced software opportunities. A similar development took place in educational software since the dominance of hypertext systems changed to a predominance of hypermedia systems in the last decade. These hypermedia learning environments usually contain a broad band width of media including text, graphics, animations, simulations, video, narration, and sound (Lemke, 1999).

Today computers in schools are both a focus of study (technology education) and a support for learning and teaching (educational technology). Rationales can be presented for both computer literacy and using computers as a modern part of educational technology. However, the types of technologies incorporated in the educational context tend to focus around the delivery of content and information to support formal learning processes. Schools are using ICT to enhance and add a new dimension to the learning and retention process, and also to increase communication between the home and school (Blaylock, 2005). Today, ICT that helps teach or encourage interaction can be presented on computers in the form of either text or in multimedia formats, including Macromedia Flash, Camtasia, Internet, PowerPoint, MS Word, photographs, videos, animation, and music. The guided drill is a microcomputer program that poses questions to students, returns immediate feedback, and selects additional questions based on the student's responses. Recent guided drill systems incorporate the basic principles of education in addition to subject matter knowledge into the computer program. ICT also can help students visualize objects that are difficult or impossible to view. One of the major advantages of ICT in the early years according to the IT learning exchange is that there is a growing 
increase of evidence to suggest that the relationship between ICT in schools and pupil attainment is increasing.

Advantage for introducing ICT in the early years is that it prepares the young children for living in a society that is permeated with technology. The new ICTs are intimately bound up in these aspects of human activity, so they clearly significant in children's learning and retention (Hayes \& Whitebread, 2006). According to Twinning (2002), computer work increases productivity and strongly suggests that there is a positive relationship between schools with good ICT resources and high standards of achievement. Poulter and Basford (2003) stated that ICT is a teaching tool. Its potential for improving the quality and standards of pupils' education is significant. One more benefit of ICT in schools is that pupils who do not have access at their homes get the chance to use them in school, therefore giving all the children an equal opportunity. It can be used as a learning tool in education to enrich the pupils learning and retention. It eases the material usage in education, perception, learning, and retention. It inspires and brings dynamism to the classroom. It shortens the time in learning, compacts knowledge and helps permanence. It provides the students to participate in the subject while arousing reading and searching interest. It carries the cases, actualities, and facts which are impossible to bring them in the class with their real faces (Aslan \& Dogdu, 1993).

Laboratory Training Model of teaching (LTM) is a method that generally focuses on the first hand information which comes from research and laboratory. In this method nothing is directly taught but the learning situation and condition are provided in a way that the learners themselves find the solution to the problem. In other words, LTM is an activity in which the learner practically experiences a specific concept with specific materials and equipment (Shabani, 2002).

It is hard to imagine learning to do science, or learning about science, without doing laboratory or field work. Experimentation underlies all scientific knowledge and understanding. Laboratories are wonderful settings for teaching and learning science. They provide students with opportunities to think about, discuss, and solve real problems. Developing and teaching an effective laboratory requires as much skill, creativity, and hard work as proposing and executing a first-rate research project. Typically, students work their way through a list of step-by-step instructions, trying to reproduce expected results and wondering how to get the right answer. While this approach has little done with science, it is common practice because it is efficient. LTM varies widely but there is certainly no substitute for an instructor circulating among the students, answering and asking questions, pointing out subtle details or possible applications, and generally guiding students' learning. Although students work informally in pairs or groups in many labs, some faculty has formally introduced cooperative learning into their labs. Some instructors rely on a lab hand-out, not to give cookbook instructions but to pose a carefully constructed sequence of questions to help students design experiments which illustrate important concepts (Hake, 1992).

One advantage of the well-designed hand-out is that the designer more closely controls what students do in the lab (Moog \& Farrell, 1996). The challenge is to design it so that students must think and be creative. In more unstructured LTM the challenge is to prevent students from getting stranded and discouraged. The purpose of the LTM is to help materialize the characteristics of events, materials, analysis, synthesis, evaluation, and recreating the materials and events and also the relationship between them. A laboratory is a suitable place in which the materials are learned 
through discovery learning and problem solving. This method can be mixed with other methods like group learning, discovery learning and so on.

Laboratory learning can increase the quality of learning and is an incentive in a learning activity. This method is very much suitable for satisfying the sense of inquisitiveness, improving the power of exploring, raising learners' critical thinking, building self-confidence and also self-satisfaction. Laboratory activities help to solve problem. In LTM learner faces with some problems tries to solve those problems by using available facilities to find the solution. In a laboratory learner gets an opportunity for experimentation and for logical thinking. Their participation in group discussion also contributes to their social growth during the process of experiment. Many concepts, rules, and principles of chemistry could be effectively taught by conducting experiments. Research in teaching through LTM in order to improve the process of teaching and learning is a necessity. It makes the educational process into a learner-centered one and gives the pupil the joy of discovery and thus motivates him/her for further learning. Together with the science education, besides bringing information to the students, supporting the development of their scientific thinking skills and submitting solutions to the daily problems are planned (Kaptan, 1999). Therefore, during an experiment, dynamism is seen in the classroom.

LTM provides the activeness of the student carries great value in terms of education. The most valid learning methods are learning by living and performing, preparing experiments, and investigating (Ivgen, 1997). Today in which science and technology are developing with a rattling rate, science education is performed with different techniques and methods. Inside these methods, one of the most efficient ones is the LTM method (Lawson, 1995). Laboratory provides the students to participate in the activities related with science and to learn the scientific method. Laboratory for students is a place where new information is developed by sighting, developing ideas, and interpreting the data (Adey, Shayer, \& Yates, 1995).

\section{Methodology}

This study was an experimental research which was performed in order to find out the effects of the treatments on the dependent variables. The relationship between the independent variables (ICT and LTM), dependant variables (achievement and retention on knowledge, comprehension, application, and skills) and the moderating variable (Gender) were examined by conducting the treatments in the two experimental groups.

\section{The Sample}

The sample of the study consisted of 120 seventh standard students from two English-medium elementary schools in Mysore city, India. From each school, 60 students attended the study, 30 from two participating classes per each school. Of the total number, 62 students were male and 58 students were female. Students were equally and randomly assigned to the treatment groups and their homogeneity was checked before the experiment. 
The sample has been selected in two stages. First the participating schools were selected and then the classes were allotted to different groups. The sampling technique adopted for choosing the schools in this study was purposive sampling because the researcher selected the schools from Mysore city based on their availability and willingness to cooperate. This is because teaching chemistry in 21 sessions for each class would have been practically impossible in other cities of the state where the researcher had no close contacts.

Because the number of seventh standard classes was more than two classes in each school, the researcher used the lottery method to select the classes for different experimental methods. In this method, the names of seven standard classes in each school were written in small papers and among them one class for ICT and one class for LTM were selected.

Table 1. The Number of Male and Female Students in Experimental and Control Groups

\begin{tabular}{|l||c||c||c||c||}
\hline \hline \multirow{2}{*}{ Groups } & \multicolumn{2}{c|}{ SCHOOL A } & \multicolumn{2}{c||}{ SCHOOL B } \\
\cline { 2 - 5 } Gender & ICT & LTM & ICT & LTM \\
\hline \hline Male & 15 & 15 & 16 & 16 \\
\hline \hline Female & 15 & 15 & 14 & 14 \\
\hline \hline Total & 30 & 30 & 30 & 30 \\
\hline
\end{tabular}

\section{Homogenizing the Groups}

Since the students selected for the treatments were from different schools, the researcher had to make sure that they would have the same abilities before the treatment. In order to obtain parallel groups for the experimental conditions, the researcher administered the Test of Higher Mental Ability in Science for homogenizing the groups. Table 2 shows the results of homogenizing test for two schools.

Table2. Details Regarding the Homogeneity of the Groups

\begin{tabular}{|l|l|l|l|l|l|l||}
\hline & \multirow{2}{*}{$\mathbf{N}$} & Mean & \multirow{2}{*}{$\begin{array}{c}\text { Std. } \\
\text { Deviation }\end{array}$} & \multicolumn{2}{|c|}{ t-test Equality of Means } \\
\cline { 1 - 1 } & & & $\begin{array}{l}\text { Sig. (2- } \\
\text { tailed) }\end{array}$ & df & Sig. \\
\hline Group 1 & 60 & 11.7667 & 2.58366 & \multirow{2}{*}{.867} & 118 & 0.05 \\
\hline \hline Group 2 & 60 & 11.7111 & 1.79415 & & & \\
\hline
\end{tabular}

The result of this test, as shown in Table 2, showed that the p-value of .867 was larger than .05 which meant that the null hypothesis assuming no difference between the means of the students from the two schools was confirmed. Thus, it was concluded that the students in the two schools were homogenous with respect to Higher Mental Ability in science. 


\section{Experimental Procedures}

After selecting the samples and homogenizing the groups, the conditions were ready to perform the experiment. The instructional software for ICT-based teaching was prepared by using Macromedia Builder software, Flash, Camtasia software, Microsoft Office and using movies, texts, animation and images.

In order to find out the justifiability of the developed instructional software, it was tried out in one class with the presence of several experts and teachers. The suggestions given by the experts and teachers were incorporated and improvements were made in the instructional software. In the same way, the contents of the related experiments were designed by adopting Laboratory Training Model by the researcher and were tried out in a class with the presence of experts and teachers. Their suggestions were incorporated and necessary modifications were made while adopting Laboratory Model of teaching for the treatment.

Then the treatment started for the groups. ICT groups were taught using computers and attractive instructional software and the LTM groups were taught by taking the students to the lab and dividing them in some groups for performing the experiments individually. Both ICT and LTM groups went through respective treatments for a period of 3 months. At the end of the relatively long treatments, the posttest was administered to both experimental groups to measure their terminal gains regarding the achievement in chemistry. After one month, the delayed posttest for achievement in chemistry was administered to all the experimental and the control groups to determine the retention level of the students.

\section{Instrumentation}

To test the hypotheses of this study, the researcher needed to use valid and reliable instruments. The following are the brief descriptions of research instruments that were used to collect the necessary data toward the purposes of the study.

\section{Test of Higher Mental Ability in Science (THMAS)}

Sansanwal and Joshi has developed and standardized this test in 1989. It assesses the higher mental abilities like application, analysis, synthesis, and evaluation in relation to science. The test contains 20 items and covers the above four abilities with 6, 6, 5 and 3 items each respectively. A few of the items are open-ended and some are multiple choice questions. Though the items make use of science content, they were designed in such a way that they assess the above mentioned abilities and not knowledge or comprehension of science content. There was no time limitation/restriction for the completion of the test. The levels of reliability and validity of the test are explained as follows: (a) Reliability: The test-retest reliability was reported to range from 0.514 
to 0.816 ( $n=110)$; and (b) Validity: The concurrent validity of the test with science achievement and general academic achievement were found to be $0.24(n=104) 0.26(n=102)$ respectively.

\section{Achievement Test in Chemistry}

The achievement test in chemistry was designed and developed by the researcher. It contains 43 items including multiple choice, short-answer, and essay-type questions. The test covered four different content areas of knowledge, comprehension, application, and skills. The test was constructed based on the content of the four chapters of the $7^{\text {th }}$ Standard Science Book of Karnataka State Syllabus. The four chapters were 'Nature and Composition of Matter', 'Water', 'Heat' and 'Acid, Bases, and Salts'. Of the total number of items in the test, 20 were multiple choice items, 12 were short-answers items, and 11 were long-answer items.

To construct the test, the researcher went through the Karnataka state syllabus science textbook of seventh standard carefully. The items were constructed from the four chapters of chemistry which were taught using ICT method and LTM.

Since the selected chapters were not equal in size and volume, the researcher had to specify the weight of the marks allotted to each chapter according to their size and volume. Finally $30 \%$ of the mark weightage was given to chapter 1 that was about 'Nature and Composition of Matter', 19\% weightage was given to chapter 2 that was about Water, 21\% weightage was given to chapter 3 that was about Heat, and finally $30 \%$ weightage was given to chapter 4 that was about Acid, Bases, and Salts. The test was designed based on the Bloom's taxonomy of objectives. The weightages were given to different objectives, thus $31 \%$ were allocated to knowledge, $29 \%$ to comprehension, $28 \%$ to application, and $12 \%$ were allocated to skills.

The weightages were also given to the type of the questions. Of the 43 items, $20 \%$ of marks were multiple choice questions, $30 \%$ of questions were allotted to short-answer type of questions, and finally $50 \%$ of questions were allotted to essay type of questions. Based on these weightage tables, the blueprint of Achievement Test in Chemistry was prepared. Table 3 shows the blueprint for the overall test of chemistry achievement.

Table 3. Blueprint for the Overall Test of Chemistry

\begin{tabular}{|l|c|c|c|c|c|c|}
\hline \multicolumn{1}{|c|}{ Objectives } & Knowledge & Comprehension & Application & Skills & $\begin{array}{c}\text { Total No. } \\
\text { of } \\
\text { questions }\end{array}$ & Total marks \\
\hline Multiple choice & 7 & 6 & 7 & - & 20 & 20 \\
\hline Short answer & 6 & 4 & 2 & - & 12 & 24 \\
\hline Long answer & - & 5 & 3 & 3 & 11 & 56 \\
\hline
\end{tabular}

The Blueprint for the Achievement Test was developed to guide the proportions of measuring the performance of the two groups of learners who were taught through the two different methods of teaching. The test covered four different content areas, each divided into several subtopics. The blueprint reflected the number of questions for each topic and indicated the type of gains tested, 
namely knowledge, comprehension, application, and skills. This blueprint helps ensure that the selected course topics are covered at an appropriate level of understanding.

Based on the blueprint, the questions of the achievement test were constructed and the draft tool was prepared by the researcher. This draft was sent to experts from the field of education and to a few seventh standard chemistry teachers. Their suggestions were incorporated and the modified draft of the test was prepared.

Because the Achievement Test in Chemistry was a researcher-constructed test, the researcher needed to make sure that the items and the tests had the necessary qualities for the purpose of validation. Toward this, first the researcher conducted a try-out of the test to see whether the test possessed the necessary characteristics of a good test and whether its items had the required characteristics including item facility, item discrimination, and choice distribution.

To test the instrument's validity and reliability, the draft of the achievement test was administered to 91 students from two schools of Mysore city. The feedback obtained from this administration was used to devise the final instrument. The final instrument was tested for reliability using testretest and Cronbach's Alpha test of reliability. The reliability coefficients obtained as a result of both procedures was 0.763 , which is an acceptable index of reliability.

To test the validity of the final instrument, the researcher established the various types of validity known as face validity, content validity, and criterion-related validity. Both the results and comments of the experts regarding these issues assured that this newly-developed test was an appropriate test and could measure what it was intended to measure. Based on these results, the test was used in the study with confidence.

\section{Results}

Because the present study was an experimental one, several null hypotheses were tested based on the obtained data. The results of these statistical tests were presented based on each subhypothesis, usually in the form of tables of findings.

Hypothesis One: There is no significant difference in performance of students taught by ICT and LTM with respect to posttest scores regarding;

a. Overall achievement in chemistry

b. Knowledge-, comprehension-, application-, and skills-components of achievement in chemistry

c. Retention of achieved knowledge in chemistry

d. Retention of knowledge of chemistry in terms of knowledge-, comprehension-, application-, and skills-components 


\section{Comparison of Overall Achievement in Chemistry (HO1a)}

To test H01a, the researcher tabulated the data of the overall achievement test of chemistry of students taught by ICT and LTM and compared them. The comparison of the means of the two groups showed the following results. Figure 1 shows the difference graphically.

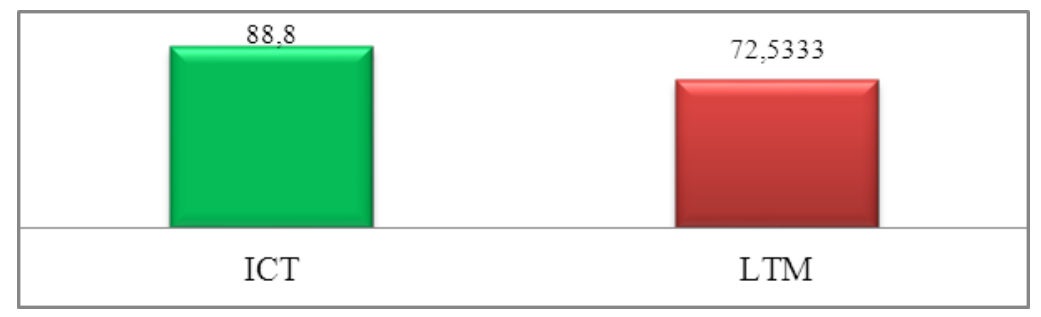

Figure1. Overall Scores of Achievement in Chemistry

To determine whether the observed differences among the two means were significant, the means scores of the two groups were subjected to the independent sample t-test with regard to LTM and ICT methods. As Table 4 shows, the t-value of 9.404 was found to be statistically significant as the $p$ value of .000 was smaller than the cut-off value of .05 . This showed that there was a significant difference between achievement levels of students taught by ICT and LTM with respect to post-test scores in overall achievement in chemistry.

Table 4. t-test Results for Overall Achievement in Chemistry

\begin{tabular}{|c|c|c|c|c|c|c|c|c|}
\hline \multicolumn{2}{|c|}{ Treatment } & $\mathbf{N}$ & Mean & Std. Deviation & Std. Error Mean & $\mathbf{t}$ & df & Sig. (2-tailed) \\
\hline Achievement & $\begin{array}{l}\text { ICT } \\
\text { LTM }\end{array}$ & $\begin{array}{l}60 \\
60\end{array}$ & \begin{tabular}{|l|}
88.8000 \\
72.5333
\end{tabular} & $\begin{array}{r}10.04374 \\
8.86820\end{array}$ & $\begin{array}{l}1.29664 \\
1.14488\end{array}$ & 9.404 & 118 & .000 \\
\hline
\end{tabular}

Comparison of the Two Groups' Achievements on Knowledge, Comprehension, Application, and Skills Levels (H01b)

To determine whether the observed differences between the two means were significant, the mean scores of the two groups were subjected to the independent sample t-test with regard to ICT and LTM in knowledge-, comprehension-, application-, and skills-components of achievement. As Table 5 demonstrates, component of knowledge with the t-value of 9.780 , component of comprehension with the t-value of 7.911, component of application with the t-value of 7.226, and component of skills with the t-value of -2.003 were found to be statistically significant as the $p$ value of .000 was smaller than the cut-off value of .05 . This showed that there were significant differences between performances of students taught by ICT and LTM with respect to post-test scores in knowledge, comprehension-, application, and skills-components of achievement test in chemistry. Figure 2 shows this different graphically. 
Table 5. t-Test Results for Components of Achievement in Chemistry

\begin{tabular}{|c|c|c|c|c|c|c|c|c|}
\hline & Treatment & $\mathbf{N}$ & Mean & $\begin{array}{r}\text { Std. } \\
\text { Deviation }\end{array}$ & $\begin{array}{r}\text { Std. Error } \\
\text { Mean }\end{array}$ & $\mathbf{t}$ & df & $\begin{array}{l}\text { Sig. (2- } \\
\text { tailed) }\end{array}$ \\
\hline Knowledge & $\begin{array}{l}\text { ICT } \\
\text { LTM }\end{array}$ & $\begin{array}{l}60 \\
60\end{array}$ & $\begin{array}{l}1.4308 \\
1.1436\end{array}$ & $\begin{array}{l}.09934 \\
.20461\end{array}$ & $\begin{array}{l}.01282 \\
.02641\end{array}$ & 9.780 & 118 & .000 \\
\hline Comprehension & $\begin{array}{l}\text { ICT } \\
\text { LTM }\end{array}$ & $\begin{array}{l}60 \\
60\end{array}$ & $\begin{array}{l}2.2050 \\
1.6606\end{array}$ & $\begin{array}{l}.37934 \\
.37453\end{array}$ & $\begin{array}{l}.04897 \\
.04835\end{array}$ & 7.911 & 118 & .000 \\
\hline Application & $\begin{array}{l}\text { ICT } \\
\text { LTM }\end{array}$ & $\begin{array}{l}60 \\
60\end{array}$ & $\begin{array}{l}1.8972 \\
1.5194\end{array}$ & $\begin{array}{l}.24899 \\
.31940\end{array}$ & $\begin{array}{l}.03214 \\
.04123\end{array}$ & 7.226 & 118 & .000 \\
\hline Skills & $\begin{array}{l}\text { ICT } \\
\text { LTM }\end{array}$ & $\begin{array}{l}60 \\
60\end{array}$ & $\begin{array}{l}4.6333 \\
4.9000\end{array}$ & $\begin{array}{l}.86998 \\
.55337\end{array}$ & $\begin{array}{l}.11231 \\
.07144\end{array}$ & 2.003 & 118 & .003 \\
\hline
\end{tabular}

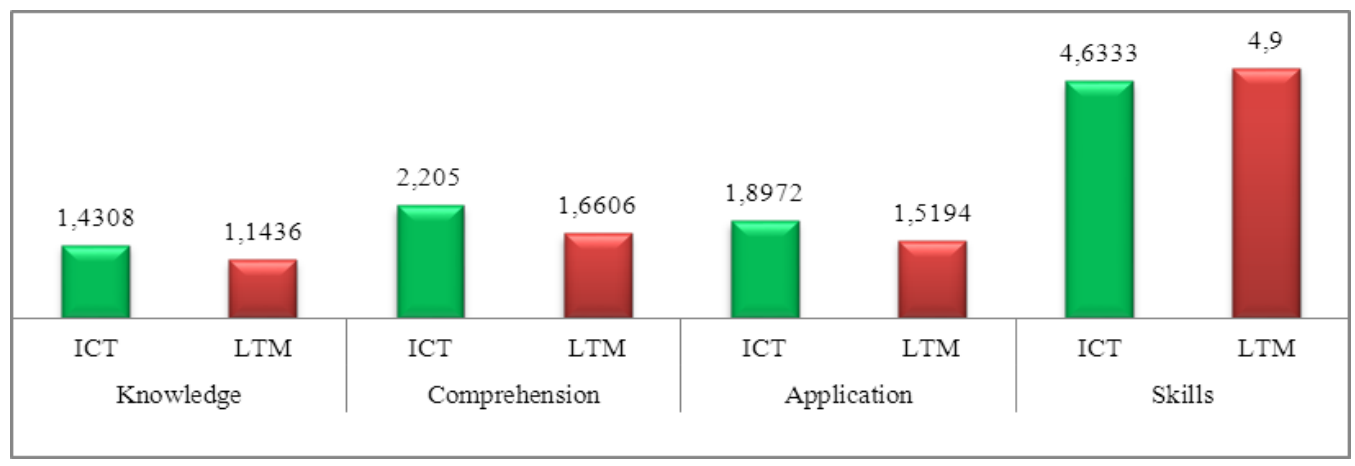

Figure 2. Scores in Components of Achievement in Chemistry

\section{Retention of Achievement in Chemistry (H01C)}

To test $\mathrm{H01C}$, the researcher tabulated the data of the retention of achievement in chemistry with regard to ICT and LTM and compared them. The comparison of the means of the two groups showed that they had different means. Figure 3 shows the difference graphically. 


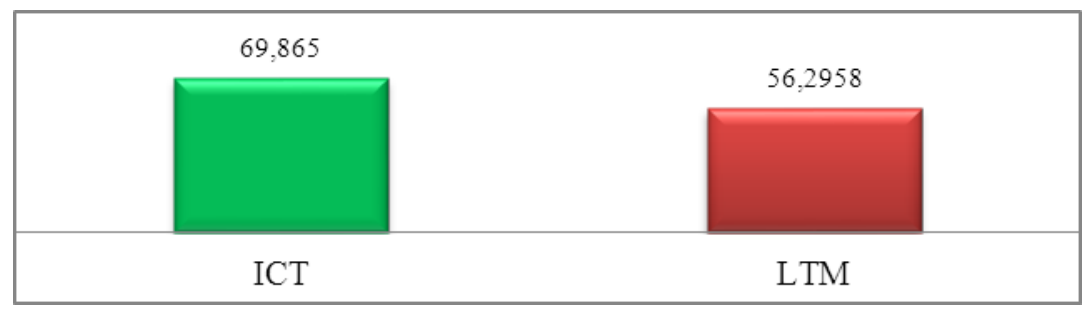

Figure 3. Retention of Achievement in Chemistry

To determine whether the observed differences among the two means were significant, the mean scores of the two groups were subjected to the independent sample t-test to with regard to ICT and LTM. As Table 6 shows, the $t$-value of 7.347 was found to be statistically significant as the $p$ value of .000 was smaller than the cut-off value of .05 . This showed that there was a significant difference between the performances of students taught by ICT and LTM methods with respect to scores of retention of achievement in chemistry.

Table 6. t-Test Results for Retention of Achievement in Chemistry

\begin{tabular}{||ll||r|r||r||r||r||r||r||}
\hline Treatment & & N & Mean & $\begin{array}{r}\text { Std. } \\
\text { Deviation }\end{array}$ & $\begin{array}{r}\text { Std. } \\
\text { Error } \\
\text { Mean }\end{array}$ & $\begin{array}{r}\text { Sig. } \\
\mathbf{t}\end{array}$ & $\begin{array}{r}\text { df } \\
\mathbf{( 2 -} \\
\text { tailed) }\end{array}$ \\
\hline \hline Retention & ICT & 60 & 69.8650 & 11.81346 & 1.52511 & 7.347 & 118 & .000 \\
& LTM & 60 & 56.2958 & 8.06981 & 1.04181 & & \\
\hline
\end{tabular}

\section{Comparison of Knowledge, Comprehension-, Application-, and Skills-Retention of Achievement} in Chemistry (H01d)

To test H01d, the researcher tabulated the data regarding the components of knowledge, comprehension-, application-, and skills retention of achievement in chemistry for students taught by ICT and LTM and compared them. The comparison of the means of the two groups showed that they had different means. Figure 4 shows the difference graphically.

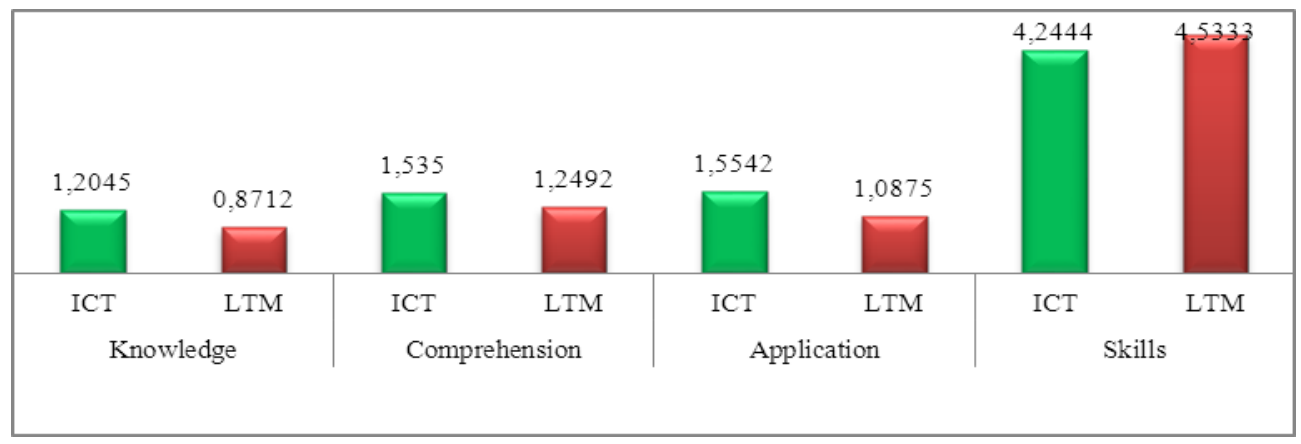

Figure 4. Overall Scores in Components of Retention of Achievement in Chemistry 
To determine whether the observed differences among the two means were significant, the raw scores of the two groups were subjected to the independent sample t-test to compare the retention scores of students taught by ICT and LTM. As Table 7 shows, component of knowledge the $t$-value of 7.674 , component of comprehension $t$-value of 4.639 , component of application the t-value of 9.230 were found to be statistically significant as the $p$ value of .000 was smaller than the cut-off value of .05 . This demonstrated that there were significant differences between performances of students taught by ICT and LTM methods with respect to retention scores in the components of knowledge, comprehension, and application-retention of achievement in chemistry. However, for the component of skills the t-value of -1.397 had no significant difference as the $p$ value of 0.165 was larger than the cut-off value of .05 .

Table 7. t-test Results for Components of Retention of Achievement in Chemistry

\begin{tabular}{|c|c|c|c|c|c|c|c|c|}
\hline & Treatment & $\mathbf{N}$ & Mean & $\begin{array}{r}\text { Std. } \\
\text { Deviation }\end{array}$ & $\begin{array}{r}\text { Std. Error } \\
\text { Mean }\end{array}$ & $\mathbf{t}$ & df & $\begin{array}{l}\text { Sig. (2- } \\
\text { tailed) }\end{array}$ \\
\hline Knowledge & $\begin{array}{l}\text { ICT } \\
\text { LTM }\end{array}$ & $\begin{array}{l}60 \\
60\end{array}$ & $\begin{array}{r}1.2045 \\
.8712\end{array}$ & $\begin{array}{l}.22666 \\
.24864\end{array}$ & $\begin{array}{l}.02926 \\
.03210\end{array}$ & 7.674 & 118 & .000 \\
\hline Comprehension & $\begin{array}{l}\text { ICT } \\
\text { LTM }\end{array}$ & $\begin{array}{l}60 \\
60\end{array}$ & $\begin{array}{l}1.5350 \\
1.2492\end{array}$ & $\begin{array}{l}.32136 \\
.35293\end{array}$ & $\begin{array}{l}.04149 \\
.04556\end{array}$ & 4.639 & 118 & .000 \\
\hline Application & $\begin{array}{l}\text { ICT } \\
\text { LTM }\end{array}$ & $\begin{array}{l}60 \\
60\end{array}$ & $\begin{array}{l}1.5542 \\
1.0875\end{array}$ & $\begin{array}{l}.30717 \\
.24292\end{array}$ & $\begin{array}{l}.03966 \\
.03136\end{array}$ & 9.230 & 118 & .000 \\
\hline Skills & $\begin{array}{l}\text { ICT } \\
\text { LTM }\end{array}$ & $\begin{array}{l}60 \\
60\end{array}$ & $\begin{array}{l}4.2444 \\
4.5333\end{array}$ & $\begin{array}{r}1.31178 \\
.91894\end{array}$ & $\begin{array}{l}.16935 \\
.11863\end{array}$ & $\begin{array}{r}- \\
1.397\end{array}$ & 118 & .165 \\
\hline
\end{tabular}

Hypothesis Two: There is no significant difference between male and female students with respect to post scores regarding;

a. Achievement in chemistry

b. Knowledge-, comprehension-, application-, and skills-components of achievement

c. Retention of achievement in chemistry

d. Knowledge-, comprehension-, application-, and skills-components of achievement in retention 


\section{Overall Achievement in Chemistry (H02a)}

To determine whether the observed differences among the two means were significant across the two genders, the mean scores of the male and female students in ICT and LTM groups were subjected to the Analysis of Variance ( $2 \times 2$ Design). As Table 8 shows, the $p$ values for gender and treatment were individually smaller than the cut-off value of .05 , which means the null hypotheses are not confirmed.

Table 8. Tests of Between-Subjects Effects

\begin{tabular}{|l|r|r|r|}
\hline Source & df & F & Sig. \\
\hline Gender & 1 & 3.987 & .048 \\
\hline Treatment & 1 & 89.886 & .000 \\
\hline Gender * Treatment & 1 & .868 & .354 \\
\hline
\end{tabular}

However, the $p$ value for the interaction between treatment and gender is .354 , which is greater than .05 , suggesting that there is no significant difference associated with the interaction between gender and treatment.

As Table 9 shows, students in ICT group performed better than students in LTM group ( $M=88.80$ versus $M=72.53)$. Female students with higher means in both ICT $(M=89.74$ versus $M=87.91)$ and LTM (75.12 versus 70.11 ) performed better than their male counterparts.

Table 9. Results of Descriptive Analysis - Overall Achievement

\begin{tabular}{|l|l|r|r|r|}
\hline \multirow{2}{*}{ Gender/Treatment } & Mean & $\begin{array}{r}\text { Std. } \\
\text { Deviation }\end{array}$ & $\mathbf{N}$ \\
\hline \multirow{3}{*}{ Male } & ICT & 87.9194 & 11.00026 & 31 \\
\cline { 2 - 5 } & Laboratory & 70.1129 & 9.64772 & 31 \\
\cline { 2 - 5 } & Total & 79.0161 & 13.63284 & 62 \\
\hline \multirow{3}{*}{ Female } & ICT & 89.7414 & 9.00756 & 29 \\
\cline { 2 - 5 } & Laboratory & 75.1207 & 7.25050 & 29 \\
\cline { 2 - 5 } & Total & 82.4310 & 10.95713 & 58 \\
\hline \multirow{3}{*}{ Total } & ICT & 88.8000 & 10.04374 & 60 \\
\cline { 2 - 5 } & Laboratory & 72.5333 & 8.86820 & 60 \\
\cline { 2 - 5 } & Total & 80.6667 & 12.47852 & 120 \\
\hline
\end{tabular}

To sum up, ICT is more effective than LTM when it comes to the students' overall achievement in chemistry and female students performed better in both methods than the male students. The interaction of treatment and gender was not significant. 


\section{Knowledge-Component of Achievement (H02b)}

To determine whether the observed differences among the two means were significant across the two genders, the mean scores of the male and female students in ICT and LTM groups were subjected to the Analysis of Variance (2x2 Design).

As Table 10 illustrates, the $p$ values for interaction of gender and treatment and gender alone were larger than the cut-off value of .05 , which means that there are no significant differences associated with the gender and interaction of gender and treatment. However, the $p$ value for the treatment is .000 which is smaller than .05 , which suggest that there is a significant difference associated with the treatment.

Table 10. Tests of Between-Subjects Effects

\begin{tabular}{|l|r|r|r|}
\hline Source & df & F & Sig. \\
\hline Gender & 1 & .316 & .575 \\
\hline Treatment & 1 & 94.095 & .000 \\
\hline Gender * Treatment & 1 & .399 & .529 \\
\hline
\end{tabular}

As Table 11 shows, as far as achievement on knowledge component is concerned, students in ICT group performed better than students in LTM group ( $M=1.4308$ versus $M=1.1436)$. Male students with higher means in both ICT $(M=1.4318$ versus $M=1.4297)$ and LTM ( $M=1.1266$ versus $M=1.1618$ ) performed relatively better than their female counterparts; however, the differences were not statistically significant.

Table 11. Results of Descriptive Analysis - Achievement on Knowledge

\begin{tabular}{|l|l|r|r|r|}
\hline \multirow{2}{*}{ Gender/Treatment } & Mean & $\begin{array}{r}\text { Std. } \\
\text { Deviation }\end{array}$ & $\mathbf{N}$ \\
\hline \multirow{4}{*}{ Male } & ICT & 1.4318 & .10636 & 31 \\
\cline { 2 - 5 } & Laboratory & & .22931 & 31 \\
\cline { 2 - 5 } & Total & 1.2792 & .23472 & 62 \\
\hline \multirow{4}{*}{ Female } & ICT & 1.4297 & .09312 & 29 \\
\cline { 2 - 5 } & Laboratory & 1.1618 & .17667 & 29 \\
\cline { 2 - 5 } & Total & 1.2958 & .19455 & 58 \\
\hline \multirow{4}{*}{ Total } & ICT & 1.4308 & .09934 & 60 \\
\cline { 2 - 5 } & Laboratory & 1.1436 & .20461 & 60 \\
\cline { 2 - 5 } & Total & 1.2872 & .21550 & 120 \\
\hline
\end{tabular}

To sum up, ICT is more effective than LTM when it comes to the students' achievement on knowledge in chemistry. Although male students performed relatively better under both methods than female students, the gender difference was not statistically significant. 


\section{Comprehension-Component of Achievement (H02b)}

As it is evident in Table 12, to determine whether the observed differences among the two means were significant across the two genders, the mean scores of the male and female students in ICT and LTM groups were subjected to the Analysis of Variance (2x2 Design).

As Table 12 presents, the $p$ values for the gender as well as the interaction between treatment and gender were larger than the cut-off value of .05 , which means that there are no significant differences associated with the gender and interaction between gender and treatment. However, the $p$ value for the treatment is .000 which is smaller than .05 , suggesting that there is a significant difference associated with the treatment.

Table12. Tests of Between-Subjects Effects

\begin{tabular}{|l|r|r|r|}
\hline Source & df & $\mathbf{F}$ & Sig. \\
\hline Gender & 1 & 1.277 & .261 \\
\hline Treatment & 1 & 62.057 & .000 \\
\hline Gender * Treatment & 1 & .670 & .415 \\
\hline
\end{tabular}

As Table 13 shows, students in ICT group performed better than students in LTM group ( $M=2.2050$ versus $M=1.6606)$. Female students with higher means in both ICT ( $M=2.2161$ versus $M=2.1946)$ and LTM ( $M=1.7299$ versus $M=1.5957)$ performed relatively better than their male counterparts but this difference was not statistically significant.

Table 13. Results of Descriptive Analysis - Achievement on Comprehension

\begin{tabular}{|l|l|r|r|r|}
\hline \multicolumn{2}{|c|}{ Gender/Treatment } & Mean & $\begin{array}{r}\text { Std. } \\
\text { Deviation }\end{array}$ & $\mathbf{N}$ \\
\hline \multirow{4}{*}{ Male } & ICT & 2.1946 & .41032 & 31 \\
\cline { 2 - 5 } & Laboratory & 1.5957 & .40595 & 31 \\
\cline { 2 - 5 } & Total & 1.8952 & .50497 & 62 \\
\hline \multirow{3}{*}{ Female } & ICT & 2.2161 & .35013 & 29 \\
\cline { 2 - 5 } & Laboratory & 1.7299 & .33072 & 29 \\
\cline { 2 - 5 } & Total & 1.9730 & .41723 & 58 \\
\hline \multirow{3}{*}{ Total } & ICT & 2.2050 & .37934 & 60 \\
\cline { 2 - 5 } & Laboratory & 1.6606 & .37453 & 60 \\
\cline { 2 - 5 } & Total & 1.9328 & .46435 & 120 \\
\hline
\end{tabular}


To sum up, ICT is more effective than LTM when it comes to the comprehension-component of achievement in chemistry. On the other hand, neither the gender effect nor the interaction effect was statistically significant.

\section{Application-Component of Achievement (H02b)}

To determine the comparison of the means of the two groups across the two genders, the mean scores of male and female students both in ICT and LTM groups were subjected to the Analysis of Variance (2×2 Design).

As Table 14 shows, the $p$ values for gender as well as for the interaction between treatment and gender were larger than the cut-off value of .05, which suggests that there are no significant differences associated with the gender and the interaction. However, the $p$ value for the treatment is .000 which is smaller than .05 , which means that there is a significant difference associated with the treatment.

Table 14. Tests of Between-Subjects Effects

\begin{tabular}{|l|r|r|r|}
\hline Source & $\mathbf{d f}$ & $\mathbf{F}$ & Sig. \\
\hline Gender & 1 & 1.535 & .218 \\
\hline Treatment & 1 & 52.630 & .000 \\
\hline Gender* Treatment & 1 & 3.651 & .059 \\
\hline
\end{tabular}

As Table 15 shows, students in ICT group performed better than students in LTM group ( $M=1.8972$ versus $M=1.5194)$. Male students with a higher mean in ICT group ( $M=1.9140$ versus $M=1.8793$ ) performed relatively better than female students, but producing no significant difference.

Table 15. Results of Descriptive Analysis - Achievement on Application

\begin{tabular}{|l|l|r|r|r|}
\hline \multicolumn{2}{|l|}{ Gender/Treatment } & Mean & $\begin{array}{r}\text { Std. } \\
\text { Deviation }\end{array}$ & N \\
\hline \multirow{3}{*}{ Male } & ICT & 1.9140 & .25389 & 31 \\
\cline { 2 - 5 } & Laboratory & 1.6034 & .34957 & 31 \\
\cline { 2 - 5 } & Total & 1.6774 & .38558 & 62 \\
\hline \multirow{3}{*}{ Female } & ICT & 1.8793 & .24684 & 29 \\
\cline { 2 - 5 } & Laboratory & 1.6034 & .26437 & 29 \\
\cline { 2 - 5 } & Total & 1.7414 & .28918 & 58 \\
\hline \multirow{3}{*}{ Total } & ICT & 1.8972 & .24899 & 60 \\
\cline { 2 - 5 } & Laboratory & 1.5194 & .31940 & 60 \\
\cline { 2 - 5 } & Total & 1.7083 & .34249 & 120 \\
\hline
\end{tabular}


To sum up, when it comes to the application-component of achievement in chemistry, ICT is more effective than LTM. However, neither the gender effect nor the interaction effect was statistically significant.

\section{Skills-Component of Achievement (H02b)}

To determine whether the observed differences among the two means were significant across the two genders, the mean scores of the male and female students in ICT and LTM groups were subjected to the Analysis of Variance (2x2 Design).

As seen in Table 16, the $p$ values for all comparisons were smaller than the set level of significance, which is assumed as .05. Therefore, the differences among the two groups from all aspects were statistically significant.

Table 16. Tests of Between-Subjects Effects

\begin{tabular}{|l|c|c|c|}
\hline Source & df & F & Sig. \\
\hline Gender & 1 & 17.987 & .000 \\
\hline Treatment & 1 & 4.407 & .038 \\
\hline Gender * Treatment & 1 & 6.128 & .015 \\
\hline
\end{tabular}

As Table 17 shows, students in LTM group performed better than students in ICT group ( $M=4.9000$ versus $M=4.6333$ ). Female students with higher means in both LTM ( $M=5.0115$ versus $M=4.7957)$ and ICT ( $M=5.0575$ versus $M=4.2366)$ performed better than male students.

Table 17. Results of Descriptive Analysis - Achievement on Skills

\begin{tabular}{|l|l|r|r|r|}
\hline \multicolumn{2}{|l}{ Gender/Treatment } & Mean & $\begin{array}{r}\text { Std. } \\
\text { Deviation }\end{array}$ & $\mathbf{N}$ \\
\hline \multirow{4}{*}{ Male } & ICT & 4.2366 & 1.01267 & 31 \\
\cline { 2 - 5 } & Laboratory & 4.7957 & .63056 & 31 \\
\cline { 2 - 5 } & Total & 4.5161 & .88280 & 62 \\
\hline \multirow{3}{*}{ Female } & ICT & 5.0575 & .36806 & 29 \\
\cline { 2 - 5 } & Laboratory & 5.0115 & .44080 & 29 \\
\cline { 2 - 5 } & Total & 5.0345 & .40315 & 58 \\
\hline \multirow{3}{*}{ Total } & ICT & 4.6333 & .86998 & 60 \\
\cline { 2 - 5 } & Laboratory & 4.9000 & .55337 & 60 \\
\cline { 2 - 5 } & Total & 4.7667 & .73824 & 120 \\
\hline
\end{tabular}


To sum up, LTM is more effective than ICT when it comes to the skills-component of achievement in chemistry, and female students performed better in both methods than male students. The interaction between treatment and gender was also significant.

\section{Retention of Achievement in Chemistry (H02c)}

The scores obtained by the two groups in the retention test were subjected to the Analysis of Variance ( $2 \times 2$ Design) to decide if their overall achievement in the delayed test were different from each other. As Table 18 shows, the $p$ values for both gender and treatment were smaller than the cut-off value of .05 .

This confirmed that the retention scores of the two groups of students taught by the two methods of ICT and LTM were significantly different. This showed that students taught by ICT retained what they had learned longer than students taught by LTM methods did. However, the $p$ value for the interaction between treatment and gender is .082 , which is greater than .05 suggesting that there is no significant difference associated with the interaction of gender and treatment.

Table 18. Tests of Between-Subjects Effects

\begin{tabular}{|l|r|r|r|}
\hline Source & df & F & Sig. \\
\hline Gender & 1 & 6.176 & .014 \\
\hline Treatment & 1 & 58.114 & .000 \\
\hline Gender* Treatment & 1 & 3.074 & .082 \\
\hline
\end{tabular}

As Table 19 demonstrates, students in ICT group performed better than students in LTM group $(M=69.8650$ versus $M=56.2958)$. Female students with higher means in both ICT $(M=73.7931$ versus $M=66.1903)$ and $\operatorname{LTM}(M=56.9741$ versus $M=55.6613)$ groups performed better than male students.

Table 19. Results of Descriptive Analysis - Retention of Achievement

\begin{tabular}{|l|l|r|r|r|}
\hline \multicolumn{2}{|l|}{ Gender/Treatment } & Mean & $\begin{array}{r}\text { Std. } \\
\text { Deviation }\end{array}$ & $\mathbf{N}$ \\
\hline \multirow{4}{*}{ Male } & ICT & 66.1903 & 14.59705 & 31 \\
\cline { 2 - 5 } & Laboratory & 55.6613 & 8.88645 & 31 \\
\cline { 2 - 5 } & Total & 60.9258 & 13.10714 & 62 \\
\hline \multirow{3}{*}{ Female } & ICT & 73.7931 & 5.90289 & 29 \\
\cline { 2 - 5 } & Laboratory & 56.9741 & 7.18951 & 29 \\
\cline { 2 - 5 } & Total & 65.3836 & 10.69895 & 58 \\
\hline \multirow{3}{*}{ Total } & ICT & 69.8650 & 11.81346 & 60 \\
\cline { 2 - 5 } & Laboratory & 56.2958 & 8.06981 & 60 \\
\cline { 2 - 5 } & Total & 63.0804 & 12.16130 & 120 \\
\hline
\end{tabular}


To sum up, ICT method is more effective than LTM when it comes to the students' retention of achievement. Also, female students performed significantly better in both methods than male students. The interaction between treatment and gender was not significant.

\section{Knowledge-Component of Retention (H02d)}

To determine whether the observed differences among the two means were significant across the two genders, the scores of the male and female students in ICT and LTM groups were subjected to the Analysis of Variance (2×2 Design).

Table 20 shows that the $p$ values for gender as well as for interaction between gender and treatment were larger than the cut-off value of .05 , which means that there are no significant differences associated with the gender and the interaction. However, the $p$ value for the treatment is .000 which is smaller than .05 , suggesting a significant difference.

Table 20. Tests of Between-Subjects Effects

\begin{tabular}{|l|r|r|r|}
\hline Source & df & F & Sig. \\
\hline Gender & 1 & 3.649 & .059 \\
\hline Treatment & 1 & 60.678 & .000 \\
\hline Gender* Treatment & 1 & 1.011 & .317 \\
\hline
\end{tabular}

As Table 21 illustrates, students in ICT group performed better than students in LTM group $(M=1.2045$ versus $M=.8712)$. Female students with higher means in both ICT $(M=1.2692$ versus $M=1.1439)$ and $\operatorname{LTM}(M=.8912$ versus $M=.8524)$ groups performed relatively better than male students but again this difference was not statistically significant.

Table 21. Results of Descriptive Analysis - Retention of Achievement in Knowledge

\begin{tabular}{|l|l|r|r|r|}
\hline \multicolumn{2}{|l|}{ Gender/Treatment } & Mean & $\begin{array}{r}\text { Std. } \\
\text { Deviation }\end{array}$ & $\mathbf{N}$ \\
\hline \multirow{4}{*}{ Male } & ICT & 1.1439 & .23646 & 31 \\
\cline { 2 - 5 } & Laboratory & .8524 & .25320 & 31 \\
\cline { 2 - 5 } & Total & .9981 & .28395 & 62 \\
\hline \multirow{4}{*}{ Female } & ICT & 1.2692 & .19985 & 29 \\
\cline { 2 - 5 } & Laboratory & .8912 & .24650 & 29 \\
\cline { 2 - 5 } & Total & 1.0802 & .29294 & 58 \\
\hline \multirow{4}{*}{ Total } & ICT & 1.2045 & .22666 & 60 \\
\cline { 2 - 5 } & Laboratory & .8712 & .24864 & 60 \\
\cline { 2 - 5 } & Total & 1.0378 & .29006 & 120 \\
\hline
\end{tabular}


To sum up, ICT is more effective than LTM in terms of the knowledge component of retention of achievement. Neither the gender effect and nor the interaction effect was significant.

\section{Comprehension-Component of Retention (H02d)}

To determine whether the observed differences among the two means were significant across the two genders, the scores of the male and female students in ICT and LTM groups were subjected to the Analysis of Variance (2×2 Design).

As Table 22 shows, the $p$ values for gender as well as for interaction between treatment and gender were larger than the cut-off value of .05, which means that there are no significant differences. However, the $p$ value for the treatment is .000 which is smaller than .05 , suggesting that there is a significant difference.

Table 22. Tests of Between-Subjects Effects

\begin{tabular}{|l|r|r|r|}
\hline Source & df & F & Sig. \\
\hline Gender & 1 & 2.205 & .140 \\
\hline Treatment & 1 & 22.570 & .000 \\
\hline Gender* Treatment & 1 & 2.815 & .096 \\
\hline
\end{tabular}

Table 23 depicts that students in ICT group performed better than students in LTM group $(M=1.5350$ versus $M=1.2492)$. Female students with a higher mean score in ICT group ( $M=1.6345$ versus $M=1.4419$ ) performed relatively better than their male students, while males with a higher mean in LTM ( $M=1.2548$ versus $M=1.2431)$ showed slightly better performance than females.

Table 23. Results of Descriptive Analysis - Retention of Achievement in Comprehension

\begin{tabular}{|l|l|r|r|r|}
\hline \multicolumn{2}{|l}{ Gender Treatment } & Mean & $\begin{array}{r}\text { Std. } \\
\text { Deviation }\end{array}$ & $\mathbf{N}$ \\
\hline \multirow{4}{*}{ Male } & ICT & 1.4419 & .36633 & 31 \\
\cline { 2 - 5 } & Laboratory & 1.2548 & .33969 & 31 \\
\cline { 2 - 5 } & Total & 1.3484 & .36283 & 62 \\
\hline \multirow{4}{*}{ Female } & ICT & 1.6345 & .23235 & 29 \\
\cline { 2 - 5 } & Laboratory & 1.2431 & .37251 & 29 \\
\cline { 2 - 5 } & Total & 1.4388 & .36558 & 58 \\
\hline \multirow{3}{*}{ Total } & ICT & 1.5350 & .32136 & 60 \\
\cline { 2 - 5 } & Laboratory & 1.2492 & .35293 & 60 \\
\cline { 2 - 5 } & Total & 1.3921 & .36545 & 120 \\
\hline
\end{tabular}


To sum up, when it comes to the comprehension-component of achievement retention in chemistry, ICT is more effective than LTM. On the other hand, neither the gender effect nor the interaction effect was significant.

\section{Application-Component of Retention (H02d)}

To determine whether the observed differences among the two means were significant across the two genders, the mean scores of the male and female students in ICT and LTM groups were subjected to the Analysis of Variance (2x2 Design).

As Table 24 below shows, the $p$ values for the gender variable and the interaction between gender and treatment were larger than the cut-off value of .05 , which means there are no significant differences associated with the gender and the interaction. However, the $p$ value for the treatment is .000 which is smaller than .05 , and this suggests a significant difference.

Table 24. Tests of Between-Subjects Effects

\begin{tabular}{|l|r|r|r|}
\hline Source & $\mathbf{d f}$ & $\mathbf{F}$ & Sig. \\
\hline Gender & 1 & 1.435 & .233 \\
\hline Treatment & 1 & 86.592 & .000 \\
\hline Gender * Treatment & 1 & 1.557 & .215 \\
\hline
\end{tabular}

Table 25 depicts that students in ICT group performed better than students in LTM group $(M=1.5542$ versus $M=1.0875)$. Female students with higher means in both ICT ( $M=1.6178$ versus $\mathrm{M}=1.4946$ ) performed relatively better than their male counterparts but both male and female groups had almost same means in LTM ( $M=1.0887$ versus $M=1.0862)$.

Table 25. Results of Descriptive Analysis - Retention of Achievement in Application

\begin{tabular}{|l|l|r|r|r|}
\hline \multicolumn{2}{|l|}{ Gender Treatment } & Mean & $\begin{array}{r}\text { Std. } \\
\text { Deviation }\end{array}$ & $\mathbf{N}$ \\
\hline \multirow{4}{*}{ Male } & ICT & 1.4946 & .34556 & 31 \\
\cline { 2 - 5 } & Laboratory & 1.0887 & .25792 & 31 \\
\cline { 2 - 5 } & Total & 1.2917 & .36512 & 62 \\
\hline \multirow{4}{*}{ Female } & ICT & 1.6178 & .25051 & 29 \\
\cline { 2 - 5 } & Laboratory & 1.0862 & .23036 & 29 \\
\cline { 2 - 5 } & Total & 1.3520 & .35887 & 58 \\
\hline \multirow{3}{*}{ Total } & ICT & 1.5542 & .30717 & 60 \\
\cline { 2 - 5 } & Laboratory & 1.0875 & .24292 & 60 \\
\cline { 2 - 5 } & Total & 1.3208 & .36186 & 120 \\
\hline
\end{tabular}


To sum up, when it comes to the application-component of retention, ICT is more effective than LTM. No other comparisons were statistically significant.

\section{Skills-Component of Retention (H02d)}

To determine whether the observed differences among the two means were significant across the two genders, the mean scores of the male and female students in ICT and LTM groups were subjected to the Analysis of Variance (2x2 Design).

As seen in Table 26, the $p$ value of treatment and interaction of gender and treatment were larger than the cut-off value of .05 , which means that the differences for these comparisons are not significant. However, the $p$ value for the gender is .354 which is smaller than .05 , suggesting that there is a significant difference associated with the gender.

Table 26. Tests of Between-Subjects Effects

\begin{tabular}{|l|r|r|r|}
\hline Source & $\mathbf{d f}$ & $\mathbf{F}$ & Sig. \\
\hline Gender & 1 & 4.112 & .045 \\
\hline Treatment & 1 & 1.938 & .167 \\
\hline Gender * Treatment & 1 & .303 & .583 \\
\hline
\end{tabular}

As Table 27 shows, students in LTM group performed relatively better than students in ICT group ( $M=4.5333$ versus $M=4.2444$ ) but the difference was not significant. Female students with higher means in both ICT ( $M=4.5172$ versus $M=3.9892)$ and $L T M(M=4.6897$ versus $M=4.3871)$ performed better than their male counterparts.

Table 27. Results of Descriptive Analysis - Retention of Achievement in Skills

\begin{tabular}{|l|l|r|r|r|}
\hline \multicolumn{2}{|l|}{ Gender Treatment } & Mean & $\begin{array}{r}\text { Std. } \\
\text { Deviation }\end{array}$ & N \\
\hline \multirow{3}{*}{ Male } & ICT & 3.9892 & 1.66107 & 31 \\
\cline { 2 - 5 } & Laboratory & 4.3871 & 1.13886 & 31 \\
\cline { 2 - 5 } & Total & 4.1882 & 1.42655 & 62 \\
\hline \multirow{2}{*}{ Female } & ICT & 4.5172 & .72147 & 29 \\
\cline { 2 - 5 } & Laboratory & 4.6897 & .58371 & 29 \\
\cline { 2 - 5 } & Total & 4.6034 & .65622 & 58 \\
\hline \multirow{3}{*}{ Total } & ICT & 4.2444 & 1.31178 & 60 \\
\cline { 2 - 5 } & Laboratory & 4.5333 & .91894 & 60 \\
\cline { 2 - 5 } & Total & 4.3889 & 1.13705 & 120 \\
\hline
\end{tabular}


To sum up, female students performed significantly better under both methods than the male students on skills-component of retention. No other comparisons were statistically significant in terms of this component.

\section{Conclusions}

Teaching chemistry through the ICT method is effective and should receive its due attention. By way of exemplification, if a student only listens to his/her teacher's description of, say, the word snow, his/her understanding of the described word is surely much weaker and more subject to forgetting than when the verbal description is reinforced by giving the learner the chance of touching and feeling the snow on a snowy day. In the latter case, the learner's mental connection with the newly learned word is through more senses than just hearing. He/she sees or even touches as well as hears about the concept of snow and this deepens his/her learning while minimizing the chance of forgetting. ICT may not be able to give the students the chance of feeling the coldness of snow and touching the snowflakes but it can bring the learners as close to the reality of this experience as technology permits. Once the learners watch a movie and listen to the descriptions about it, they actually approach the new topic in question from both the visual and the auditory channels. This makes the understanding of the topic easier for them.

In this study, the researcher-made instructional clips, animations, instructional movies and pictures which were based on the content of the science books gave the learners the chance of learning the chemistry concepts through more senses than just hearing and provided them with the opportunity to observe relationships that could never be explained by the other methods. Through ICT, learners could use texts, sound, picture, animation, and videos simultaneously and were accordingly better at learning chemistry. The researcher would also like to conclude that the use of films, clips, photos, slides, the Internet and the like can both make the learners more interested in the subject under discussion and help them understand those same concepts by making them more tangible and less abstract.

When it came to the achievement in the knowledge-, comprehension-, application-, and skills components of chemistry, the ICT method was more effective than the LTM in the case of all the four components. Therefore, both male and female students equally benefit from ICT and are negatively affected by the LTM. Similarly, as far as the overall achievement is concerned, the ICT method of teaching chemistry was found to be much more effective than the LTM. Also, as for the effects of the two methods of teaching on the retention of learned materials, the findings of the study suggested that students taught through ICT method of teaching chemistry retained what they had learned better than the students who were taught through the LTM. This was true both for the overall achievement and the individual components of the achievement in chemistry.

Gender had no effect on the overall achievement in chemistry as the performance of the male and female students in the overall achievement test of chemistry did not show any statistically significant difference. The same results were found when the male and female students' scores were compared in each of the four components of the achievement in chemistry. There was no significant interaction between the effect of treatment and gender of students taught by ICT and 
LTM in respect to their overall achievement in chemistry, nor was there an interaction between the effects of gender and treatment in relation to their scores with regard to the knowledge-, comprehension-, and application components of achievement in chemistry. However, female students taught by ICT performed better than the male students taught by the same method in the skills-component of chemistry. This was the only visible difference in terms of gender of the elementary students participating in the study.

Based on the results of this study, several recommendations can be made both for practice and future research. First, technology does not bring any success without appropriate instructional strategies so that educators should employ ICT with proven teaching and learning approaches in science education. Second, ICT often appears to be associated with multimedia in education; thus, full capacity of contemporary multimedia should be utilized when designing ICT courseware. Third, gender issues should not be completely ignored when integrating ICT in education. Fourth, new studies should be conducted with secondary and even college students in order to test the results of this study coming from elementary students. Finally, future research should identify sensitivities among learner characteristics, subject matter areas, and interactive learning technologies with regard to their compatibilities for best practices.

\section{References}

Adey, P., Shayer, M., \& Yates, C. (1995). Thinking science (Second edition). Surrey, UK: Nelson.

Aslan, Z. \& Dogdu, S. (1993). Egitim teknolojisi uygulamalari ve egitim araclari [Educational technology applications and educational instruments]. Ankara: Tekisik Ofset.

Blaylock, T. H. (2005). The impact of computer-based primary education. Journal of Education, 125(3), 373-384.

Hake, R. R. (1992). Socratic pedagogy in the introductory physics lab. Physics Teacher, 30, 546-552.

Hayes, M. \& Whitebread, D. (2006). ICT in the early years. Milton Keynes: Open University Press.

Ivgen, R. (1997). Biyoloji araştirmaları rehberi [Biological research guide]. Istanbul: Milli Egitim Basimevi.

Kaptan, F. (1999). Fen bilgisi ogretimi [Teaching science]. Istanbul: Milli Egitim Basimevi.

Lawson, A. E. (1995). Science teaching and the development of thinking. Belmont, CA: Wadsworth.

Lemke, C, (1999). Professional competency continuum: Professional skills for the digital age classroom. Santa Monica, CA: Milken Exchange on Educational Technology.

Moog, R. \& Farrell, J. (1996). Chemistry: A guided inquiry. New York: John Wiley and Sons.

Poulter, T. \& Basford, J. (2003). Using ICT in foundation stage teaching. Glasgow: Bell and Bain.

Sansanwal, D. N. \& Joshi. A. (1989). Manual for test of higher mental ability in science (THMAS). Agra: National Psychological Corporation.

Shabani, D. B. (2002). Increasing social initiations in children with autism: Effects of a tactile prompt. Journal of Applied Behavior Analysis, 35, 79-83. 
Tinio, L. V, (2003). ICT in education. E-ASEAN Task Force, VNDP-APDIP.

Twinning, P. (2002). Conceptualising computer use in education: Introducing the computer practice framework (CPF). British Educational Research Journal, 28(1), 95-110.

Ya'acob, A., Mohd Nor, N. F., \& Azman, H. (2005). Implementation of the Malaysian Smart schools: An investigation of teaching-learning practices and teacher-student readiness. Internet Journal of e- Language Learning \& Teaching, 2(2), 16-25.

Correspondence: Alireza Badeleh, Visiting Instructor, Department of Studies in Humanities, Islamic Azad University, Sari, Mazandaran, Iran 